\title{
The Research on the Insurance Industry's Tax Burden in China under the Background of Change from Business Tax to VAT
}

\author{
Kewei Chen \\ Department of Finance and Taxation, Jinan University, Guangzhou, China \\ Email: kwchan100@163.com
}

How to cite this paper: Chen, K.W. (2018) The Research on the Insurance Industry's Tax Burden in China under the Background of Change from Business Tax to VAT. Modern Economy, 9, 734-749. https://doi.org/10.4236/me.2018.94048

Received: March 12, 2018

Accepted: April 23, 2018

Published: April 26, 2018

Copyright $\odot 2018$ by author and Scientific Research Publishing Inc. This work is licensed under the Creative Commons Attribution International License (CC BY 4.0).

http://creativecommons.org/licenses/by/4.0/

\section{c) (i) Open Access}

\begin{abstract}
The insurance industry plays a key role in the national economy and modern society. The tax policy has a wide range of influences on the development of the insurance industry and the tax burden is the core of tax policy, which is directly related to the business performance and the balance of the insurance market. This paper estimates insurance companies' effective tax rate of business tax and income tax by selecting insurance companies' financial statement data from 2008 to 2015 . We can see that the effective tax rate of insurance industry is facing a heavy tax burden especially for property insurance industry. By studying these problems, we should pay more attention to the tax burden on the insurance companies in the implementation of value-added tax in order to achieve the basic goal about change from business tax to VAT that does not increase but decreases slightly the tax burden and eliminates the double taxation. We also should solve the problems and challenges of insurance companies, facing change from business Tax to VAT, thus promoting the development of the insurance industry and enhancing its international competitiveness.
\end{abstract}

\section{Keywords}

Insurance, Tax Burden, Change from Business Tax to VAT

\section{Introduction}

The insurance industry, which has the functions of insurance protection and financing, is an important part of China's financial market. On August 13, 2014, the State Council issued the "Several Opinions on Accelerating the Development of Modern Insurance Business", referred to as the "new ten policies of insur- 
ance", which made it clear that insurance is an important means of modern economy's important industries and risk management and also an important standard of social civilization, economic development and social governance. In 1980, there was only one in-service insurance company in China. And there were 165 insurance companies with premium income reaching 3.1 trillion yuan by the end of 2016. The size of the insurance market surpassed Germany, France and Britain with ranking third in the world in 2016. However, the density and depth of world average insurance in 2016 were 1.89 and 1.51 times that of China. Most insurance companies have large fluctuations in their profit margins, and the overall cost ratio for premium business is more than $80 \%$. The industry's profit margin is relatively low. Tax policy is an important means of regulation and the most direct impact of policy changes is reflected in the tax burden. A reasonable tax burden not only promotes the development of insurance companies, but also promotes the development of the country's economy.

This article analyzes the tax burden of the insurance industry when the Chinese insurance industry begins to be collected in VAT, and combines the problems faced by insurance companies to provide ideas for the further expansion of China's insurance industry taxation policy, so that the reform of the insurance's business tax system is more in line with the needs of the national economy and the development of the industry, and can improve the level of development of the insurance industry and the level of international competitiveness. The greatest contribution of this paper is to divide insurance companies into different scales and operating characteristics to measure and compare the tax burden. The article data is true and reliable. However, this article does not carry out empirical regression.

The article is organized as follows: firstly, sort out domestic and foreign literature from the aspects of the tax system, the tax burden measurement, the impact of tax burden and the impact of the reform of the insurance industry. Secondly, define the definition of tax burden and use economic theory to analyze the effect of tax burden on insurance demand and supply. Thirdly, compare the tax burden of China's insurance companies of different sizes, the tax burden on property and life insurance, and the tax burden of the insurance industry and other financial industries. Finally, put forward opinions and suggestions on the problems faced by the insurance industry after the reform.

\section{Literature Review}

\subsection{Research on the Tax System of Insurance Industry}

Whether the insurance industry should be taxed, Ngee-Choon \& John Whalley and Grubert \& Mackie [1] [2] argue that financial services do not add or change consumer preferences nor change utility functions, only changing consumers' budgetary constraints over time and should not be taxed. It is only necessary to impose VAT on individual consumption at different periods. Alan Schenk [3] pointed out that under the imposition of the VAT model, the insurance industry 
has a higher tax burden than other financial industries. Therefore, the life insurance industry and hidden services should be exempted from taxation. The argument that the financial industry should be taxed argues that the provision of financial services create the value and consume the resource. Boadway \& Keen [4] argues that it is reasonable to impose VAT, but how to charge VAT in practice is difficult. Scholars in China generally believe that tax policies can adjust demands and a reasonable tax system will benefit the development of the insurance industry. Alan J. Auerbach [5] believes that VAT in the financial and insurance industry is more likely to reduce transaction costs and improve operational efficiency than other taxes. Ma Entao [6] argues that the current tax system of business tax and VAT results in the interruption of the deduction chain in the finance and insurance industry. Sheng Hetai [7] believes that tax exemption can be implemented for quasi-public insurance business and property insurance can be implemented value-added tax in order to get through the deduction chain.

\subsection{Research on the Tax Burden of the Insurance Industry}

Regarding to the measurements of tax burden, One method is based on profit, that is "total tax burden = total tax/(total profits + business taxes and surcharges)". One method is based on cash flow. Zimmerman [8] proposes to measure in terms of operating cash flow, that is, "(total tax - variation in investment tax deductions - deferred tax )/operating cash flow". One method is based on business income, that is, "tax burden for turnover tax = turnover tax/insurance income". The latter two methods can apply to companies that are on the verge of loss or loss, but ignore the impact of profitability.

With regard to the tax burden on the insurance industry, domestic scholars generally believe that the business tax burden in China's insurance industry is high, and the income tax burden is high and unfair. But researches paid more attention to the business tax burden after 2008. Liu Chuwang [9] analyzes the data from 2006 to 2008 and finds that the business tax burden and income tax burden of insurance companies are different among different businesses, and the tax burden varies differently among different companies. Yin Yinpin [10] and others believe that excessive and unfair taxation erodes profits, adds an additional burden on improving management, service, and technology, and affects insurance companies' retention of reserves and solvency, which in turn affects the premium rate and the insurance demand. Further, it will have a negative effect on the increase of the company's capital, affecting the premium rate and insurance demand.

Regarding to the impact of tax burden on insurance companies, one is the impact on the scale of assets. Wheaton [11] uses the regression of data from the United States life insurance companies from 1966 to 1981 to show that premium taxes have a negative effect on asset growth. One is the impact on the supply and demand of the insurance market. Zou Adams [12] analyzes the impact of taxes on insurance procurement behavior of 235 listed companies in China from 1997 
to 1999 and finds that tax burdens affect insurance demands. One is the tax burden on insurance company profits. Fang Xueqin [13] argues that business tax has a negative impact on the insurer's return on net assets and long-term solvency, the latter being more significant, but not significant for the cash ratio. Zhang Dezhou [14] and others think that business tax burden has a negative impact on profit.

\subsection{Research on the Impact of Replacing the Business Tax with VAT}

With regard to the impact of tax burdens, Tian Zhiwei [15] constructs the CGE model and finds that the tax burden of the insurance industry was reduced after the reform. And it could promote the growth of total output. Wei Zhihua and Xia Yongzhe [16] use the basic tax exemption model to calculate and find a huge decline in the tax burden on the insurance industry. However, using the simple method to calculate the tax burden of the insurance industry, especially the life insurance industry will increase significantly. Peng Xuemei [17] [18] find that the overall tax burden of smaller companies after the reform is higher than that of large companies.

With regard to the accounting and insurance pricing, Li Fang and Liu Hongwei [19] point out that the insurance business involves a wide range of areas and financial management is weak. The reform will increase the difficulty of financial accounting, and have higher requirements for financial information. Tax burden is an important factor for insurance companies to price their products. $\mathrm{Ma}$ Zhongchao [20] believes that reform will affect the pricing of insurance products. Huang Mingli (2015) and Wang Daomeng [21] think that reform will affect the sales model and business model of insurance companies.

\subsection{A Brief Review}

A large number of documents are targeted at the entire financial industry and the number of studies on the insurance industry alone is relatively small. With regard to the study of the tax burden on the insurance industry, foreign scholars start earlier and their theoretical and empirical studies are very rich. Most domestic studies are based on theoretical analysis and comparative analysis, and many researches only describe the taxation system of insurance business tax and point out its problems. There is a small part of empirical analysis, but the sample size is generally not big enough. Recently, many domestic scholars have studied the influence of the reform on the insurance industry, and analyzed the problems of the taxation, taxation, and tax burden of the insurance industry under the background of the reform.

\section{Theoretical Analysis of Tax Burden in Insurance Industry}

\subsection{Definition and Classification of Tax Burden}

The tax burden is generally expressed as the ratio between the amount of tax 
paid and the tax base, which is the economic burden on the taxpayer for fulfilling its tax liability. In addition to the connotation of the tax burden, it is necessary to define the extension of the tax burden. Firstly, the tax burden should not include the excess tax burden. The welfare loss brought by the tax burden to the taxpayer is called the excessive tax burden. Secondly, the tax burden should include the cost of taxes. Thirdly, the tax burden should not include various non-tax burdens. To determine a reasonable tax burden, we should analyze the reasonable limits of the tax burden qualitatively and quantitatively.

Considering the taxation system and the actual situation of the insurance industry in China, this paper calculates the actual tax burden of insurance companies according to the ETR (Effective Tax Rate) proposed by American scholar Nicholas R. Lady and most OECD countries [22] [23] [24].

The formula is as follows:

$$
\begin{aligned}
\text { ETR } & =\frac{\text { Business tax and surcharge }+ \text { Income tax }}{\text { Net profit }+ \text { Business tax and surcharge }+ \text { Income tax }} \\
& =\text { BETR }+ \text { IETR }
\end{aligned}
$$

$\mathrm{ETR}=($ Business tax and surcharge + Income tax $) /($ Net profit + Business tax and surcharge + Income tax $)=$ BETR + IETR.

\subsection{Theoretical Analysis of Tax Burden in Insurance Industry}

\subsubsection{Impact of the Tax Burden on Insurance Demand}

As shown in Figure 1, the $\mathrm{X}$-axis represents the demand for insurance products, the $\mathrm{Y}$-axis represents the demand for other financial alternatives, and the consumer's budget constraint is " $A B$ ". Regardless of the taxation situation, $C_{1}$ is the equilibrium point of the insurance market and the insurance demand is $X_{1}$. The imposition of a business tax on insurance products will result in the actual tax burden being passed on to consumers, so the price of insurance products will increase. On the one hand, because of the income effect, the real income of consumers is reduced, a new budget constraint " $A$ " " $B$ " is generated, a new market

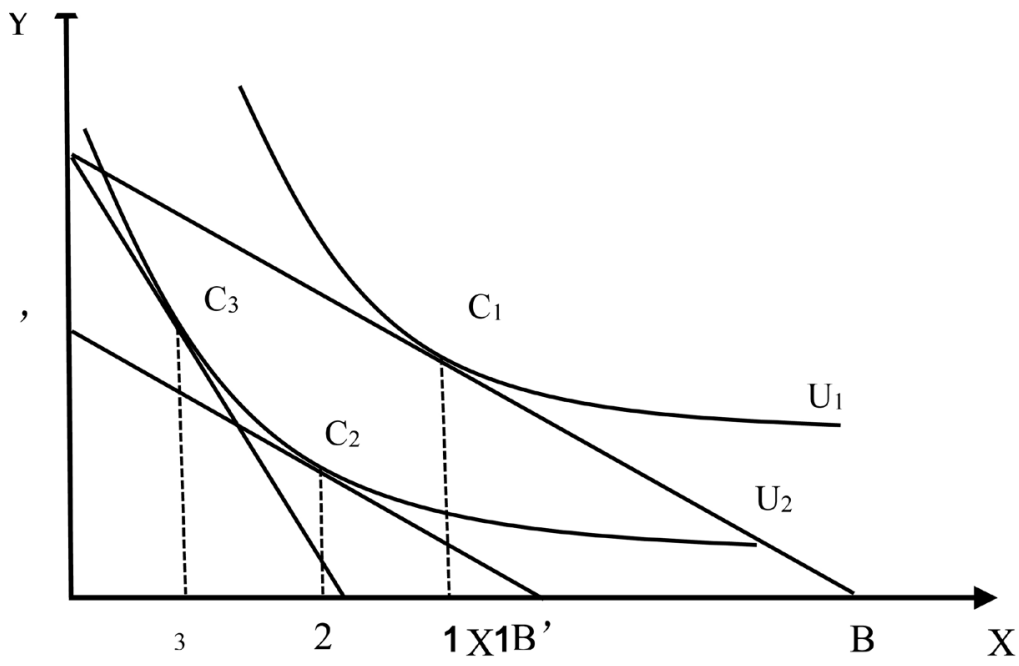

Figure 1. Impact of taxation on insurance demand. 
equilibrium point $C_{2}$ is formed, the demand for insurance goods drops to $X_{2}$, and $X_{1}$ to $X_{2}$ are the result of income effect. On the other hand, insurance products have financial management functions and sales service integration, making it an alternative. As prices increase, consumers tend to substitute other low-priced commodities and the slope of the budget constraint line changes. At this time, the equilibrium point becomes $\mathrm{C}_{3}$, the demand for insurance commodities falls to $\mathrm{X}_{3}$. $\mathrm{X}_{2}$ to $\mathrm{X}_{3}$ are the result of substitution effects. Due to the effect of substitution effect and income effect, the demand of insurance goods drops from $X_{1}$ to $X_{3}$.

\subsubsection{The Impact of Tax Burden on Insurance Supply}

In the market economy, companies provide the quantity and quality of goods according to the principle of maximizing profits. Supply refers to the number of commodities that producers are willing to sell at a certain price for a certain period of time. The supply of goods and prices appear to change in the same direction. As an exogenous variable, business tax mainly has the following effects on the supply of insurance products: Firstly, how much business tax is paid most directly affects the amount of operating costs. Secondly, how much business tax is paid directly affects the cash flow of the insurance company, which affects the efficiency of the use of funds. Thirdly, the increase in tax burden affects the company's profits. The reduction of distributable profits will inevitably reduce the accumulation of total reserves. The shortage of reserves will increase the risks of company operations and policyholders, affect the long-term development of insurance companies, and make it difficult to increase the supply of commodities. Finally, it also affects the future expectations of producers for the product.

\subsubsection{The Impact of Tax Burden on the Balance of Insurance Market}

The business tax affects the balance of the entire insurance market by affecting the needs of consumers and the supply of insurance companies. As shown in Figure 2, The $\mathrm{X}$-axis is the number of insurance goods and the $\mathrm{Y}$-axis is the price of insurance goods. The market supply line $\mathrm{D}_{1}$ is a curve that slopes to the

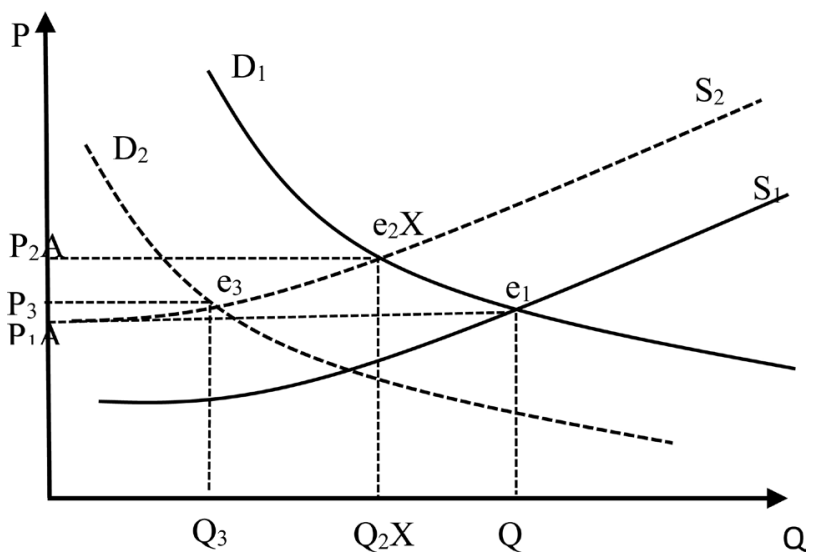

Figure 2. Effect of taxation on the equilibrium of insurance market. 
upper right. The supply is positively related to the price of insurance products. The market demand line $S_{1}$ is a curve that is inclined from the upper left to the lower right. There is a negative correlation between demand and price.

Without considering the business tax, the market equilibrium state is that $\mathrm{D}_{1}$ intersects with $S_{1}$ at $e_{1}\left(P_{1}, Q_{1}\right)$. Considering the business tax, on the one hand, the increase in the price of insurance products will shift the insurance company's supply curve to $S_{2}$, and the equilibrium state of the market is that $S_{2}$ and $D_{1}$ intersect at $e_{2}\left(P_{2}, Q_{2}\right)$. On the other hand, the substitution effect and the income effect shift the demand curve to the left to $\mathrm{D}_{2}$, thus forming the final market equilibrium and equilibrium point $\mathrm{e}_{3}\left(\mathrm{P}_{3}, \mathrm{Q}_{3}\right)$. As shown in Figure 2, the market equilibrium quantity decreased from $\mathrm{Q}_{2}$ to $\mathrm{Q}_{3}$ after the business tax was levied on the insurance industry. Which one is big between the equilibrium price $\mathrm{P}_{1}$ and $\mathrm{P}_{3}$ depends on the elasticity of consumer demand. If consumers have a rigid demand for insurance products, the demand curve shifts to the left relatively little, and the new equilibrium price $\mathrm{P}_{3}$ is higher than the initial equilibrium price $\mathrm{P}_{1}$. Otherwise, the new equilibrium price $\mathrm{P}_{3}$ will be lower than the initial equilibrium price $\mathrm{P}_{1}$.

\section{General Analyses of China's Insurance Tax Burden}

\subsection{China's Insurance Industry Tax System}

The tax system of the insurance industry reflects the reform of the financial market and the tax system in the financial industry. In the early 1980s, the insurance industry adopted a tax-free policy on its operations, and then gradually established a standard tax system after 1983. Table 1 shows the development history of China's insurance industry tax system.

\subsection{Comparative Analysis of Tax Burden in Insurance Industry}

The business tax rate for the insurance industry fell to 5\% from January 1, 2003 and the corporate income tax rate was unified to 25\% from January 1, 2008. Therefore, we select the data after 2008 for statistical analysis. The total market share of the selected insurance companies occupies more than $90 \%$ of the market, and companies that do not have sound financial statement data are excluded. The data is real and reliable and can effectively represent the entire market.

\subsubsection{Analysis of Tax Level and Structure of Insurance Industry}

From the perspective of the taxation of the insurance industry, business tax and corporate income tax are their main taxes, which are slightly different from the banking and securities industries. As shown in Figure 3, from 2008 to 2015, the business tax of the insurance industry accounted for $34.62 \%$ of all taxes, and income tax accounted for $21.57 \%$. The total of the two accounts for about $60 \%$. Personal income tax is paid by the insurance company as an agent. The vehicle and vessel usage license plate tax (VVULPT) is deducted and paid by the insurance 
Table 1. Development history of China's insurance industry tax system.

\begin{tabular}{|c|c|}
\hline Year & Regulations \\
\hline $1983-1987$ & $\begin{array}{l}\text { Business tax rate: } 5 \% \text {; The tax base: business income } \\
\text { Corporate income tax rate: } 55 \% \\
\text { Adjustment tax rate: } 20 \% \text { (after } 1985 \text { adjustment tax rate was changed to } 15 \% \text { ) } \\
\text { Adjustment tax and income tax are halved by local and central authorities }\end{array}$ \\
\hline $1988-1990$ & Stamp duty collected at $0.03 \%$ of insurance coverage \\
\hline $1990-1993$ & Stamp duty collected at $0.1 \%$ of premium \\
\hline 1994-1996 & $\begin{array}{l}\text { Business tax rate: } 5 \% \\
\text { Fixed resource adjustment tax was cancelled in } 1994\end{array}$ \\
\hline $1997-2000$ & $\begin{array}{l}\text { Business tax rate: } 8 \% \text {, of which } 5 \% \text { is turned over to the state, and } 3 \% \text { goes to local } \\
\text { finance } \\
\text { Corporate Income Tax Rate of Chinese-funded Insurance Companies: } 33 \%\end{array}$ \\
\hline 2001-2003 & $\begin{array}{l}\text { Since } 2001 \text {, the business tax rate of the insurance industry has been reduced by } 1 \\
\text { percentage point each year, and within three years, the business tax rate of the finan- } \\
\text { cial services industry has been reduced from } 8 \% \text { to } 5 \%\end{array}$ \\
\hline 2004-2015 & $\begin{array}{l}\text { Business tax rate: } 5 \% \\
\text { Corporate income tax rate: } 25 \%\end{array}$ \\
\hline 2016- & From May 1,2016 , the insurance industry pays VAT at $6 \%$ of premium income \\
\hline
\end{tabular}

Source of the data: Collated and compiled according to the policy documents on the Chinese tax official website.

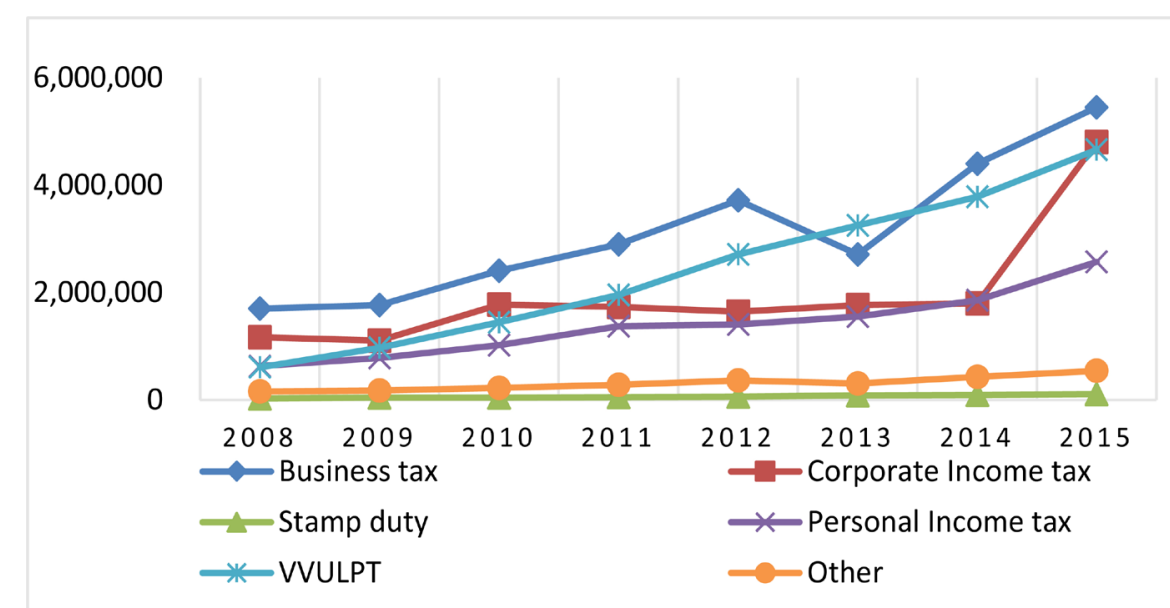

Source of data: Calculated and compiled according to relevant data of the "China Tax Yearbook" of the past years.

Figure 3. Tax structure of china's insurance industry.

company as an agent when having Motor vehicle accident liability compulsory insurance. These two taxes are not the subject of this article.

From the perspective of the trend of taxation, business tax revenue in the insurance industry has increased year by year from 2008 to 2015, with an average annual growth rate of $18.09 \%$. Business tax increases as premium income increases year by year, but it grows faster. The average annual growth rate of cor- 
porate income tax is $7.44 \%$, of which, the average annual growth rate of domestic capital is $6.37 \%$, and the average annual growth rate of foreign capital is $36.21 \%$. This is because the small-scale foreign capital base generates a faster growth rate. The year-on-year increase in corporate income tax in 2015 was mainly due to the adjustment of China's policies and regulations on the calculation of provision for preparation.

\subsubsection{Comparative Analysis of Tax Burden in Insurance Industry}

1) Comparison of tax burden between life insurance and property insurance

As shown in Table 2, from the perspective of the overall tax burden of the life insurance industry, the average tax burden from 2008 to 2015 was $23.17 \%$, indicating that the proportion of the insurance company's tax expenditures to profits was about $20 \%$, of which, the average income tax burden was $17.38 \%$ and the averages business tax burden was 5.79\%.The relatively low tax burden on business tax is mainly due to the fact that the premium income of the personal insurance of one year or more is exempted from business tax, indicating that the tax policy of China has a significant impact on the tax burden on the insurance industry. The average tax burden of the property and casualty insurance industry is about $56 \%$, of which, the business tax burden is significantly higher than the income tax burden, indicating that the property insurance company's tax burden was heavy.

2) Comparison of the tax burden of insurance companies of different scales

This article refers to the classification criteria in most studies and divides the size of insurance companies according to different market shares, dividing the market share by more than $8 \%, 1 \%-8 \%$, and below $1 \%$ into large, medium, and small insurance companies. The specific division is shown in Table 3.

Judging from the tax burden of companies of different sizes, small and

Table 2. Tax burden of life insurance and property insurance.

\begin{tabular}{ccccccc}
\hline & \multicolumn{3}{c}{ Life Insurance } & \multicolumn{3}{c}{ Property Insurance } \\
\cline { 2 - 6 } 2008 & ETR & BETR & IETR & ETR & BETR & IETR \\
\hline 2009 & 0.2011 & 0.0537 & 0.1474 & 0.5873 & 0.4564 & 0.1309 \\
2010 & 0.2079 & 0.0508 & 0.1571 & 0.5772 & 0.4731 & 0.1041 \\
2011 & 0.1847 & 0.0514 & 0.1333 & 0.5749 & 0.4473 & 0.1276 \\
2012 & 0.2185 & 0.0701 & 0.1484 & 0.5637 & 0.4422 & 0.1215 \\
2013 & 0.2028 & 0.0453 & 0.1575 & 0.5820 & 0.4511 & 0.1309 \\
2014 & 0.2353 & 0.0510 & 0.1843 & 0.5363 & 0.4006 & 0.1358 \\
2015 & 0.3532 & 0.0932 & 0.2601 & 0.4668 & 0.3390 & 0.1278 \\
2016 & 0.2542 & 0.0265 & 0.2277 & 0.3698 & 0.2472 & 0.1226 \\
\hline $\begin{array}{l}\text { Average } \\
\text { Source of data: Calculated and compiled according to relevant data of the “China Insurance Yearbook" of } \\
\text { the past years. }\end{array}$ & 0.2317 & 0.0579 & 0.1738 & 0.5666 & 0.4440 & 0.1226 \\
\hline
\end{tabular}


Table 3. Classification of insurance companies and tax burden.

\begin{tabular}{ccccc}
\hline & Scale & ETR & BETR & IETR \\
\hline \multirow{3}{*}{ Life Insurance } & Large & 0.2099 & 0.0516 & 0.1583 \\
& Medium & 0.2650 & 0.1280 & 0.1370 \\
& Small & 0.2251 & 0.0691 & 0.1560 \\
Property Insurance & Large & 0.5888 & 0.4581 & 0.1307 \\
& Medium & 0.6100 & 0.5206 & 0.0893 \\
& Small & 0.6010 & 0.5032 & 0.0978 \\
& Agricultural Insurance & 0.3268 & 0.2324 & 0.0945 \\
\hline
\end{tabular}

Source of data: Calculated and compiled according to relevant data of the "China Insurance Yearbook" of the past years.

medium-sized insurance companies are significantly higher than large insurance companies. On the one hand, large insurance companies have a market share of more than $70 \%$ in china. Large-scale insurance companies' operating methods and management methods are relatively mature. With the expansion of scale, scale effects are significant and the profitability rate is relatively high. The insurance market is similar to the oligopoly market. The higher market access threshold has squeezed the competition in small and medium-sized markets, and the profitability of small and medium-sized companies is relatively low. The business tax of the insurance industry is levied according to a certain percentage of premium income. Even if it is in a loss, the insurance company still pays business tax as long as there is premium income. On the other hand, this is in line with the theory that the larger the company is, the lower the proportion of compliance costs is.

In view of the different nature of insurance companies, the tax burdens are not the same. Export credit insurance, agricultural insurance, and reinsurance all enjoy preferential tax policies due to their own characteristics. Table 3 also clearly shows that tax burdens of agricultural insurance companies, China Credit Insurance Corporation and China Reinsurance Corporation are significantly lower than those of other companies, and continued preferential policies have also increased the stability of the company's operations.

\subsubsection{Comparison of Tax Burden between the Insurance Industry and Other Financial Industries}

As shown in Figure 4 \& Figure 5, there are differences in the tax burden among various industries within the financial industry. The tax burden on property insurance is significantly higher than that of other financial institutions such as the banking industry and the securities industry, and life insurance is at the lowest level. The business tax burden of property insurance is significantly higher than that of other financial industries, and the income tax burden on life and property insurance is lower than that of other financial industries. On the one hand, business tax and income tax are the main types of taxes in the insurance industry, but 


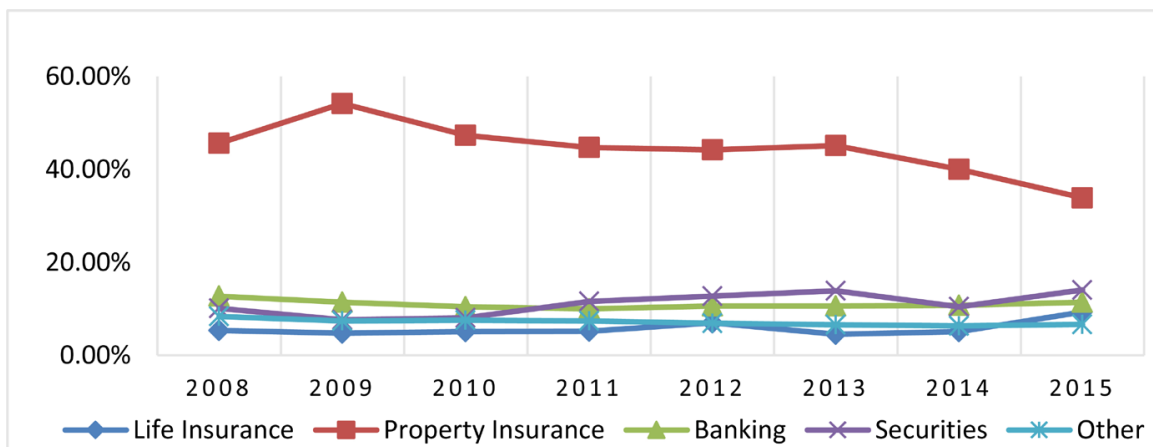

Figure 4. Comparison of business tax burden between the insurance industry and the non-insurance financial industry.

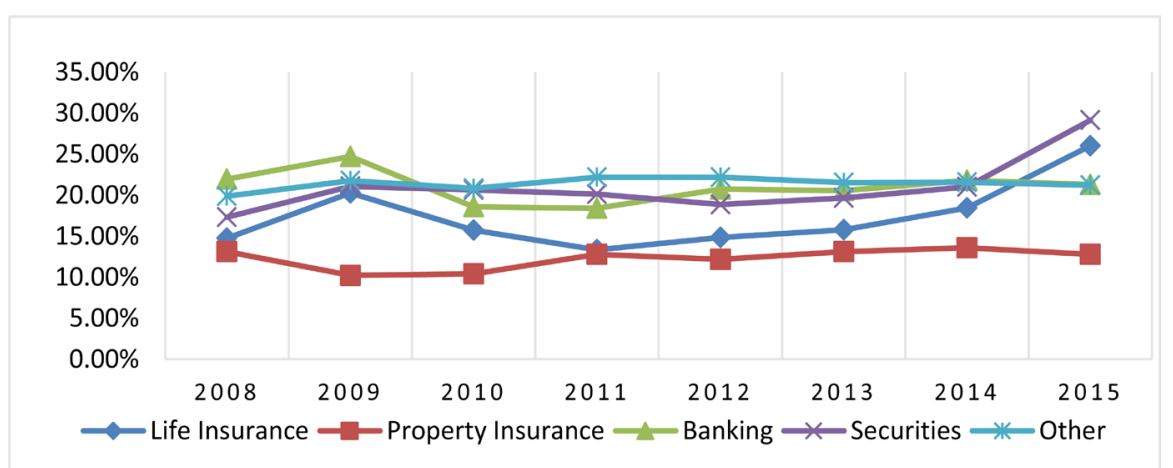

Source of data: Calculated and compiled according to relevant data of the "China Insurance Yearbook" and "China Financial Yearbook" of the past years.

Figure 5. Comparison of income tax burden between the insurance industry and the non-insurance financial industry.

stamp duty is relatively low. While the stamp duty of securities and banking accounts for a large proportion. On the other hand, life insurance has a lower tax burden due to preferential tax policies.

From the perspective of changes in tax burden, statistical data objectively reflect the economic effects of tax policies. The overall tax burden of life insurance companies showed a downward trend. The main reason is that the financial crisis in 2008 caused a large number of losses in the insurance industry. The tax burden was at a high level in 2008 and 2009, but as the crisis dissipated, the tax burden showed a downward trend.

Similarly, for the banking industry, etc. are also affected by the 2008 financial crisis environment, the decline in net profit led to an increase in the tax burden. The overall economic environment was optimized in 2010 and 2011, with strong profitability, rapid business growth, and relatively reduced tax burden. China's five consecutive rate cuts in 2014, the stock market's black swan event in 2015, and the tightening of supervision in the era of securities dealers and big assets have affected profitability, leading to an increase in income tax revenue in 2015. This shows that China's financial industry is heavily influenced by policies and the economic environment. 


\section{Challenges and Problems after China's Insurance Industry Reformed from Business Tax to VAT}

\subsection{Risk of Increasing Tax Burden}

\subsubsection{Policy Lag Leads to Short-Term Increase in Tax Burden}

In the first three months of VAT for the insurance, the insurance company's tax burden has increased rather than decreased. We find that the interest income earned on these non-standard assets and unexpired corporate bond held by the company is not included in the scope of taxation under the business tax system. However, there was no continuation of the tax exemption policy during the initial period of the reform. Subsequent fiscal and taxation (2016) No. 140 stipulates that non-capitalized income obtained during the holding period of financial commodities does not belong to income of interest, and VAT is not levied on them. However, there is still controversy over how to levied VAT on the form of financial products in accordance with regulations. If the contract does not clearly specify whether it is capital-guaranteed income or not, the problem has not been completely resolved. In addition, under the business tax system, the positive and negative differences in the transfer of financial products can be transferred to the next fiscal year for offsetting, but after the reform, it must not be carried forward across fiscal years.

\subsubsection{Insufficient Deductible Input Tax Increases Tax Burden}

1) Direct compensation mode is not conducive to input tax deduction

Insurance companies are light asset-type companies. There are three main cost expenditures: compensation costs, management fees and commission expenses. The company of life insurance basically adopts the cash compensation method. Although the company of property insurance has the cash compensation method and the repair compensation method, the proportion of the latter method is smaller. The compensation cost is the largest cost expense, most of the compensation payments are difficult to obtain input VAT invoices for deduction.

2) Agency costs are not easy to obtain input tax invoices

Insurance companies in China have a relatively traditional business model. And the sales model relies mainly on personal agents and intermediary agencies. The company directly pays commissions to individuals. Personal insurance agents cannot directly obtain VAT invoices. Therefore, it is difficult to carry out the pattern of deductions. Although the current regulations can be deducted by the tax authorities on behalf of the invoice, the regulations also require monthly commission income to reach 30,000 yuan to meet the requirements. However, in view of the current industry level, the number of people who can meet this standard and report to the tax bureau to open the offset invoices is very small.

\subsubsection{Problems in the Confirmation of Tax Practices}

The regulations of the regional tax bureaus on the need to report tax-free products are not uniform. The regulations of "inspection of sales behavior" by the regional tax bureaus are also not uniform. 


\subsection{Increased Tax Risk}

Tax risk includes two aspects: Firstly, when the insurance company has tax violations or does not follow the tax law, it will face various tax penalties and reputational damage and other risks in order to fulfill all the tax obligations. Secondly, insurance companies' understanding of tax laws is not accurate enough. If there is a lack of tax planning and more taxes are paid, they will bear the unnecessary tax burden.

\subsubsection{Increased Risk of Tax Compliance}

VAT has higher requirements for tax compliance and the legality of tax compliance. The uniform and strict VAT standards are uniformly collected by the IRS, and the supervision is vigorous, raising the bottom line of tax compliance. In addition, the collection of VAT is more complicated than the business tax in reality. In particular, the complexity of insurance companies involved in the business brings difficulties to the tax treatment to some extent.

\subsubsection{Invoice Management Problems Highlighted}

The value-added tax management emphasizes the "three-in-one", that is, invoice flow, logistics and capital flow should be consistent. Firstly, insurance companies have a large amount of funds. For the sake of prevention and control of risks, the general headquarters adopts a centralized management and graded authorization model, which is centrally managed by the headquarters. The procurement of materials is centralized and unified by the headquarters, and the suppliers distribute the goods directly to the branches. The cost is usually shared by the branch company. Secondly, policyholders pay premiums when they purchase insurance, but compensations are often paid to beneficiaries. In addition, the insurance company has many customers and a large amount of business. Increases or decreases in insurance premiums or even surrendering from time to time often require frequent invalidation and red-rush operations. The demand for special invoices for scarlet letters is very high.

\subsubsection{Uncertainty in Tax Policy}

In the process of linking VAT and business tax, there are some uncertainties between the tax policy and the specific implementation, which trigger tax risks and even increase the tax burden. For example, an insurance company uses a method of physical compensation payments to obtain value-added tax invoices, but this method has the risk of being deemed to be deemed as sales. If they are deemed to be deemed as sales, they will increase the output tax scope and push up the cost of taxation.

\section{Policy Advice}

\subsection{Define Specific Policies to Implemented Purposes of Tax Reduction}

\subsubsection{Unify and Improve Interpretations and Practical Applications}

The introductions of new policies and regulations all have more or less practical 
problems. The timely and accurate interpretation of policies and regulations can reduce the bias and adverse effects of taxpayers due to misunderstandings. In order to ensure consistency, more accurate and detailed explanatory documents are needed to unify the collection and management caliber in tax collection and management. Efforts need to be made to solve problems in practice and improve the tax collection and management system. At the same time, the government should actively promote the construction of informatization in various regions, improve tax collection and management methods and procedures, continuously improve tax collection and management efficiency, reduce the cost of tax collection, and increase inspection efforts.

\subsubsection{Innovation Input Tax Deduction and Invoice Management}

In view of the difficulty of obtaining input deductions for compensation and commissions expenses, this article proposes an innovative deduction method for insurance companies. For example, the compensation and commission expenses can be changed from invoice deduction to paper deduction. Given a certain percentage, the book can be calculated in proportion to the amount of input tax that can be deducted.

For the problems brought about by the "Three-in-one", this paper proposes to innovate the invoice management of insurance companies. First, the insurance company collects the sales and input tax of each branch, then sets certain rules, and then distributes them to the branches, so that the branches can be declared and paid for in the local market, at the same time, actively promotes the use of electronic invoices to improve the efficiency of tax collection and management.

\subsection{Insurance Companies Strengthen Tax Planning and Prevent Tax Risks}

\subsubsection{Adopt Effective Tax Planning to Reduce Tax Burden}

Companies should optimize revenue structure, continue to promote product innovation, master input tax credit rules, choose a reasonable compensation method to obtain effective input tax invoices, and effectively reduce corporate tax burden. First of all, the company need strengthen cooperation with intermediaries that can provide VAT special votes, and implement special management on VAT special votes to provide support for effective tax planning, secondly, in the process of selecting suppliers for cooperation, rational use of tax planning, reducing daily expenses to improve economic efficiency. Finally, it is possible to seek tax incentives from the government.

\subsubsection{Strengthen the Construction of Internal Control System to Prevent Tax Risks}

The insurance company should set up a corresponding tax risk management department to increase investments in the tax risk management. On the one hand, the company has practically strengthened cost awareness and risk awareness and reduced financial costs by improving its internal information system and improving the quality of its employees. On the other hand, it optimizes the 
internal control system and adapts to the taxation environment for VAT as soon as possible, effectively preventing tax risks. Tax planning should also pay attention to risks and reduce tax risks to an acceptable low level so as to truly achieve tax reductions.

\section{References}

[1] Chia, N.-C. and Whalley, J. (1999) The Tax Treatment of Financial Intermediation. Journal of Money, Credit and Banking, 31, 704-719. https://doi.org/10.2307/2601218

[2] Grubert, H. and James, M. (2000) Must Financial Services Be Taxed under a Consumption Tax? National Tax Journal, 53, 23-40. https://doi.org/10.17310/ntj.2000.1.02

[3] Schenk, A. (2009) Taxation of Financial Services (Including Insurance) under a US Value-Added Tax. Tax Law Review, No. 63, 409-442.

[4] Boadway, R. and Keen, M. (2003) Theoretical Perspectives on the Taxation of Capital Income and Financial Services. World Bank and Oxford University Press, Oxford.

[5] Auerbach, A.J. and Gordon, R.H. (2002) Taxation of Financial Services under a VAT. American Economic Review, 92, 411-416. https://doi.org/10.1257/000282802320191714

[6] Ma, E.T. (2010) Thoughts on Value-Added Tax Collection in Financial Services Industry. Tax Study, No. 9, 64-67.

[7] Sheng, H.T. (2014) Research on China's Insurance Industry VAT System Design Based on Different Nature of Business. Insurance Research, No. 10, 64-70.

[8] Zimmerman, J.L. (1983) Taxes and Firm Size. Journal of Accounting and Economics, 5, 119-149. https://doi.org/10.1016/0165-4101(83)90008-3

[9] Liu, C.W. (2010) Empirical Analysis of Tax Burden in China's Insurance Industry and Reform Suggestions. Finance and Economics Review, No. 4, 32-39.

[10] Yin, Y.P. and Wei, Y. (2012) The Comparison and Reflection on the Tax Burden of China's Insurance Industry Circulation Tax. Tax Research, 11, 36-38.

[11] Wheaton, W. (1986) The Impact of State Taxation on Life Insurance Company Growth. National Tax Journal, 39, 85-95.

[12] Zou, H. and Adams, M.B. (2006) The Corporate Purchase of Property Insurance: Chinese Evidence. Journal of Financial Intermediation, 15, 165-196. https://doi.org/10.1016/j.jfi.2004.06.007

[13] Fang, X.Q. (2010) Research on the Effect of China's Insurance Business Tax on the Solvency of Life Insurance Companies. Hunan University, Changsha.

[14] Zhang, D.Z. (2015) Research on the Circulation Tax Reform of China's Insurance Industry under the Background of Reform and Increase of Business. Shandong University, Jinan.

[15] Tian, Z.W. and Hu, Y.J. (2014) The Dynamic Influence of "Replace the Business Tax with VAT" on Financial Economy: Analysis Based on CGE Model. Financial Research, No. 2, 4-18.

[16] Wei, Z. and Xia, Y. (2015) The Impact of Tax Reform in the Financial Industry and the Choice of Policies. Economic Development, No. 8, 71-83.

[17] Peng, X. and Huang, X. (2016) The Impact of "Replace the Business Tax with VAT" on the Tax Burden of China's Insurance Industry: A Comparative Study of Large, 
Medium and Small Insurance Companies. Insurance Research, 3, 32-44.

[18] Peng, X. and Liu, D. (2017) Challenges and Countermeasures after "Replace the Business Tax with a VAT” in Insurance Industry. China Insurance, No. 4, 16-20.

[19] Liu, H. (2016) Research on the Financial Impact and Countermeasures of Insurance Company of "Replace the Business Tax with VAT". Friends of Accounting, 14, 106-109.

[20] Ma, Z. (2017) A Brief Talk on the Impact of the "Replace the Business Tax with VAT" on the Pricing of Insurance Products. Modern State-Owned Enterprise Research, No. 16, 161-163.

[21] Wang, D. (2017) On the Influence of "Replace the Business Tax with VAT" of Insurance Marketing. Taxation, No. 28, 14.

[22] Nicholas, R.R. (2000) China's Unfinished Economic Reform. China Development Press, Beijing.

[23] Li, X. (2011) Tax System, Effect and Perfect Mechanism of Insurance Industry in China. Insurance Research, No. 1, 39-45.

[24] Zheng, S. (2010) An Empirical Study on the Change of Insurance Tax System in China and the Tax Burden of Insurance Companies. Management World, No. 10, 169-170. 